\title{
UPAYA ORANGTUA DALAM MEMBIMBING PELAKSANAAN IBADAH SALAT REMAJA PENGGUNA MEDIA SOSIAL DI DESA PARGARUTAN DOLOK ANGKOLA TIMUR
}

\author{
Desi Indriani, Agus Salim Lubis \& Maslina Daulay \\ IAIN Padangsidimpuan \\ agussalimlubis2@gmail.com
}

\begin{abstract}
Parents play an important role in instructing and advising adolescents in performing prayers but there are still many teenagers who do not do fardu prayer. From that the researcher wanted to know about the parents' efforts and the obstacles they faced in guiding the implementation of adolescent prayer for social media users in Pargarutan Dolok, East Angkola District. This research method with a descriptive approach in the form of qualitative research that seeks to describe according to phenomena, events and social activities. Data collection through observation and interviews in Pargarutan Dolok, Angkola Timur District, South Tapanuli Regency. The results of the study showed that parents in guiding the implementation of prayer by adolescents who are social media users by giving advice to adolescents to carry out fardu prayers then told adolescents to perform fardu prayers. The obstacles faced by parents in guiding the implementation of adolescent prayer services for social media users are the lack of religious awareness in adolescents, economic and occupational factors, knowledge factors and various kinds of television media and mobile phones.
\end{abstract}

Keywords: Adolescents, Social Media Users, and Prayers.

\begin{abstract}
Abstrak
Orangtua memegang peranan penting dalam menyuruh dan menasehati remaja dalam melaksanakan salat akan tetapi masih banyak anak remaja yang tidak mengerjakan salat fardu. Dari itu peneliti ingin mengetahui tentang upaya orangtua dan hambatan yang dihadapi dalam membimbing pelaksanaan ibadah salat remaja pengguna media sosial di desa Pargarutan Dolok Kecamatan Angkola Timur. Metode penelitian ini dengan pendekatan deskriptif dalam bentuk kualitatif yaitu penelitian yang berusaha menggambarkan sesuai fenomena-fenomena, peristiwa dan aktivitas sosial. Pengumpulan data melalu observasi dan wawancara di desa Pargarutan Dolok Kecamatan Angkola Timur Kabupaten Tapanuli Selatan. Hasil penelitian menunjukkan bahwa orangtua dalam membimbing pelaksanaan salat remaja pengguna media sosial dengan cara memberikan nasehat pada remaja agar melaksanakan salat fardu kemudian menyuruh remaja agar melaksanakan salat fardu. Adapun hambatan yang dihadapi orangtua dalam membimbing pelaksanaan ibadah salat remaja pengguna media sosial adalah kurangnya kesadaran beragama dalam diri remaja, faktor ekonomi dan pekerjaan, faktor pengetahuan serta faktor berbagai macam media televisi dan handphone.
\end{abstract}

Kata Kunci: remaja, pengguna media sosial, dan salat. 
148 | TAZKIR: Jurnal Penelitian Ilmu-ilmu Sosial dan Keislaman

Vol. 04 No. 1 Juni 2018

\section{PENDAHULUAN}

Bimbingan orangtua terhadap ibadah salat anak remaja dalam rumah tangga sangatlah penting, karena anak merupakan amanah dan tanggung jawab dari Allah SWT yang harus dibimbing dengan sebaik mungkin agar menjadi generasi yang soleh. Selain itu orangtua adalah sebagai pembimbing utama dan yang pertama bagi anak-anaknya untuk menumbuhkan sikap keberagamaan anak remaja terutama dalam mengerjakan kewajiban sebagai hamba Allah SWT yaitu melaksanakan salat fardu.

Bimbingan adalah suatu pemberian bantuan untuk seseorang yang diberikan dalam bentuk arahan, nasehat maupun petunjuk untuk menempuh dalam suatu keadaan yang lebih baik, demi untuk tercapainya suatu tujuan yang diinginkan. Istilah "bimbingan" merupakan "guidance", kata guidance yang kata dasarnya "guide" mempunyai beberapa arti, yaitu menunjukkan jalan, memimpin, memberikan petunjuk, mengatur, mengarahkan, dan memberikan nasehat. ${ }^{1}$

Salat merupakan ibadah yang pertama kali diwajibkan oleh Allah SWT kepada manusia. Salat wajib dilakukan setiap seorang muslim pada waktu yang ditentukan dengan syarat-syarat serta rukun-rukun tertentu yang telah disyari'atkan.

Dalam Al-Qur'an surah At-Tahrim ayat 6 Allah berfirman sebagai

berikut:

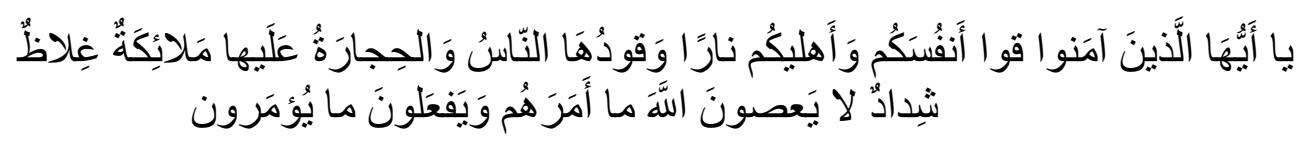

Artinya: "Hai orang-orang yang beriman, peliharalah dirimu dan keluargamu dari api neraka yang bahan bakarnya adalah manusia dan batu; penjaganya malaikat-malaikat yang kasar, keras, dan tidak mendurhakai Allah terhadap apa yang diperintahkan-Nya kepada mereka dan selalu mengerjakan apa yang diperintahkan". ${ }^{2}$

Dari ayat di atas dijelaskan bahwa seorang ayah harus membimbing keluarganya, salah-satunya yaitu dengan memelihara dirinya dan keluarganya

\footnotetext{
${ }^{1}$ Tohirin, “Bimbingan Dan Konseling Di Sekolah Dan Madrasah," in Jakarta: PT Raja Grafindo Persada, 2014, hlm.15, http://journal2.um.ac.id/index.php/sembk/article/view/1475/786.

2 Departemen Agama R.I. Al-Quran dan Terjemahannya (Jakarta : Al Faith, 2005), hlm. 561
} 
agar terhindar dari api neraka dan memerintahkan agar selalu mengerjakan apa yang telah diperintahkanNya.

Adapun hadis tentang perintah agar orangtua menyuruh anaknya untuk melaksanakan ibadah salat adalah sabda Rasulullah Saw sebagaimana riwayat di bawah ini:

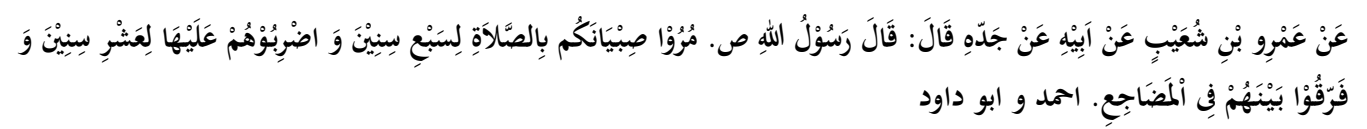

Artinya: Dari 'Amr bin Syu'aib, dari ayahnya, dari datuknya, ia berkata : Rasulullah SAW bersabda, "Suruhlah anak-anak melakukan salat pada (usia) tujuh tahun, dan pukullah mereka (bila lalai) atasnya pada (usia) sepuluh tahun, dan pisahkanlah mereka pada tempat-tempat tidur". [HR. Ahmad dan Abu Dawud] $]^{3}$

Dari hadis di atas jelas bahwa orangtua mempunyai kewajiban untuk membimbing anaknya kepada kebaikan. Apabila seorang anak mencapai umur tujuh tahun, orangtua menyuruhnya melaksanakan salat, meskipun anak itu belum wajib melaksanakannya. Demikian juga dengan anak yang sudah menginjak usia remaja, orangtua wajib menyuruhnya untuk melaksanakan shalat karena anak sudah wajib melaksanakan ibadah salat fardu.

Di zaman kemajuan Ilmu Pengetahuan dan Teknologi (IPTEK) yang sudah sangat pesat, muncul berbagai macam aplikasi-aplikasi canggih seperti: Facebook, Youtube, Instagram, Whatsapp, dan sebagainya, sehingga makin memudahkan manusia untuk mencari sesuatu. Melalui media sosial ini, perkawanan dan persahabatan menjadi sangat mudah untuk diakses dan memudahkan untuk berkomunikasi baik jarak jauh maupun jarak dekat tanpa harus bertatap muka dan bertemu. Remaja adalah salah satunya pengguna media sosial pada zaman sekarang ini. Banyak remaja yang menggunakan media sosial tidak dapat mengontrol waktunya sehingga dia lupa akan kewajibannya sebagai umat Islam.

Berdasarkan pengamatan awal peneliti di Desa Pargarutan Dolok Kecamatan Angkola Timur, bahwa kebanyakan orangtua di Desa Pargarutan Dolok Kecamatan Angkola Timur adalah rajin, patuh dan ta'at melaksanakan ibadah dalam kehidupan sehari-hari terutama ibadah salat fardu. Dapat dilihat

\footnotetext{
3 Al-Iman Abu Zakariya Yahya Bin Syarif An-Nabawi,Terjemahan Riyadu Sholihin,Diterjemahkan oleh Ahmad Sunarto (Jakarta: Pustaka Amani, 1999), hlm. 318.
} 
150 | TAZKIR: Jurnal Penelitian Ilmu-ilmu Sosial dan Keislaman

Vol. 04 No. 1 Juni 2018

bahwa orangtua masih banyak melaksanakan salat fardhu di surau-surau dan mesjid. Namun berbeda dengan hal itu, banyak anak remaja yang kurang mau beribadah, banyak remaja yang mengabaikan ibadah salat, apalagi anak remaja yang menggunakan media sosial; padahal mereka mengetahui bahwa hukum melaksanakan salat merupakan kewajiban. ${ }^{4}$

Jumlah keseluruhan remaja yang berusia 15-19 tahun di desa Pargarutan Dolok Kecamatan Angkola Timur sebanyak 31 orang dengan rincian remaja lakilaki 13 orang dan remaja perempuan 18 orang. Setelah peneliti melakukan obsevasi langsung kepada remaja yang ada di Desa Pargarutan Dolok Kecamatan Angkola Timur peneliti dapat menggambarkan bahwa anak remaja yang benar-benar aktif di media sosial berjumlah 10 orang. Remaja laki-laki berjumlah 3 orang dan remaja perempuan berjumlah 7 orang. Adapun remaja lainnya memiliki aplikasi-aplikasi canggih di HP nya tapi tidak aktip dalam menggunakan media sosial. ${ }^{5}$

Adapun menurut hasil wawancara dengan ibu Leli sebagai orangtua remaja diperoleh informasi sebagai berikut:

Anak saya memang malas melaksanakan salat, apalagi sekarang anak saya mempunya HP android, dia selalu sibuk dengan HP nya. Jika saya tidak menyuruhnya untuk melaksanakan salat ia tidak akan mengerjakan. Satu sampai dua kali saya menyuruhnya selalu jawabannya iya tapi tidak pergi sampai nanti ketiga kalinya itupun harus dinasehati dulu baru pergi melaksanakan salat. Anak sekarang memang susah dikasih tahu. ${ }^{6}$

Adapun hasil wawancara dengan Indra sebagai anak remaja diperoleh informasi bahwa:

Saya memang malas mengerjakan salat karena kalau saya mau melaksanakan salat pasti saya kerjakan tapi saya gak suka dipaksa-paksa. Jadi kalau orangtua saya menyuruh saya melaksanakan salat, kalau lagi rajin saya laksanakan tapi kalau lagi malas saya masuk kamar dan diam aja di situ. ${ }^{7}$

Dalam keadaan ini, usaha orangtua dalam membimbing pelaksanaan salat remaja sangat dibutuhkan karena bimbingan orangtua merupakan faktor

${ }^{4}$ Observasi, di Desa Pargarutan Dolok Kec. Angkola Timur, Pada Tanggal 11 Maret 2017

${ }^{5}$ Observasi, di Desa Pargarutan Dolok Kec.Angkola Timur, Pada Tanggal, 16 Maret 2017

${ }^{6}$ Ibu leli, Orang Tua Remaja di Desa Pargarutan Dolok, Wawancara, pada tanggal 20 Mei 2017.

${ }^{7}$ Indra, Remaja di Desa Pargarutan Dolok, Wawancara, pada tanggal 28 Mei 2017. 
utama dalam membimbing ibadah salat remaja. Orangtua sudah selayaknya membimbing anak supaya menjalankan ibadah salatnya.

Berdasarkan latar belakang masalah yang telah dijelaskan diatas, maka peneliti mengangkat suatu penelitian dengan judul "Upaya Orangtua Dalam Membimbing Pelaksanaan Ibadah Salat Remaja Pengguna Media Sosial di desa Pargarutan Dolok Kecamatan Angkola Timur".

Penelitian ini difokuskan pada upaya orangtua dalam membimbing pelaksanaan ibadah salat remaja pengguna media sosial. Remaja yang dimaksud adalah remaja yang berumur 15-19 tahun. Adapun pelaksanaan ibadah salat remaja yang peneliti maksud adalah pelaksanaan ibadah berupa salat fardu.

\section{KAJIAN PUSTAKA}

\section{Upaya Orangtua Terhadap Anak}

Agama Islam tidak hanya mengatur tentang cara beribadah dan berbakti kepada Allah SWT, tetapi juga mengatur tentang cara membimbing dan mendidik anak dalam keluarga atau rumah tangga. Upaya dapat diartikan dengan "usaha, ikhtiar, akal (untuk mencapai suatu maksud, memecahkan permasalahan, mencari jalan keluar)" ${ }^{8}$ Adapun orangtua adalah pimpinan dalam suatu rumah tangga yang menentukan terhadap baik buruknya kehidupan keluarga.Kemudian orangtua juga merupakan ayah dan ibu kandung (yang dianggap tua, cerdik, pandai, dan ahli), orang yang dihormati, disegani di kampung. ${ }^{9}$ Upaya orangtua adalah usaha orangtua untuk merealisasikan apa yang diinginkan. Dalam hal ini tentunya berkaitan dengan usaha orangtua dalam membimbing remaja kepada pengamalan agama khususnya dibidang ibadah shalat fardhu.

Ada beberapa upaya yang perlu menjadi perhatian orangtua terhadap anak remaja yaitu sebagai berikut: ${ }^{10}$

1. Karena orangtua merupakan pembimbing pribadi yang pertama bagi anak, dan tokoh yang ditiru anak maka sepatutnya memiliki kepribadian yang baik. Jika orangtua mempunyai sikap akhlakul karimah dan kebiasaan rajin dalam ibadah seperti melaksanakan shalat, maka akan berpengaruh terhadap kepribadian remaja sehingga mempermudah orangtua dalam mengembangkan fitrah beragama sesuai dengan ajaran-ajaran agama Islam.

${ }^{8}$ Depdikbud. Kamus Besar Bahasa Indonesia, (Jakarta: Balai Pustaka. 2001), hlm. 1250

${ }^{9}$ Depdikbud. Kamus Besar Bahasa ..., hlm. 802

${ }^{10}$ Syamsu Yusuf, Psikologi Perkembangan Anak E Remaja (Bandung: PT. Rosdakarya, 2011),, hlm 138-139. 
152 | TAZKIR: Jurnal Penelitian Ilmu-ilmu Sosial dan Keislaman

Vol. 04 No. 1 Juni 2018

2. Orangtua hendaknya memperlakukan anak dengan baik, sikap dan perlakuan oragtua yang baik akan mendengar keluhan anak dan meluruskan kesalahan anak dengan pertimbangan atau alasan yang tepat. Begitu juga hanya dalam ajaran agama jika anak salah segera diluruskan kesalahannya seperti, anak tidak melaksakan perintah Allah hendaklah orangtua memperlakukannya dengan baik dengan cara menasehati agar tidak melakukan kesalahan.

3. Orangtua hendaknya memelihara hubungan yang harmonis antara anggota keluarga. Jalinan hubungan harmonis antara remaja dan orangtua akan menimbulkan sikap saling keterbukaan dari pihak remaja kepada anggota keluarga dan lingkungan sekitarnya. Sehingga sikap remaja disaat seperti inilah, memudahkan orangtua memberikan bimbingan, terutama bimbingan mengenai pengamalan agama.

4. Orangtua hendaknya membimbing, mengajarkan, melatih, menyimak, mengevaluasi bacaan, memberitahukan ajaran agama yang baik dan menjauhkan dari perbuatan yang dilarang Allah SWT.

Dari beberapa penjelasan diatas bahwa setiap orangtua harus berupaya mempunyai kepribadian yang baik, memperlakukan anak dengan baik, dan menciptakan hubungan yang harmonis. Kemudian dalam membimbing pengamalan agama yang baik, harus melalui pembinaan, pemahaman, serta pembiasaan dalam pengamalan agama seperti menyuruh, mengajak, mengajari serta menasehati anak agar aktif dalam menjalankan perintah Allah SWT.

Dalam hadis ada tentang perintah agar orangtua menyuruh anaknya untuk melaksanakan ibadah shalat. Hal ini sesuai dengan riwayat Rasulullah Saw di bawah ini:

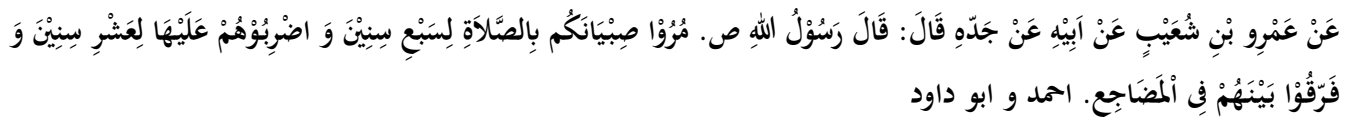

Artinya: Dari 'Amr bin Syu'aib, dari ayahnya, dari datuknya, ia berkata : Rasulullah SAW bersabda, "Suruhlah anak-anak melakukan shalat pada (usia) tujuh tahun, dan pukullah mereka (bila lalai) atasnya pada (usia) sepuluh tahun, dan pisahkanlah mereka pada tempat-tempat tidur". [HR. Ahmad dan Abu Dawud $]^{11}$

Dari hadis diatas jelas bahwa orangtua mempunyai kewajiban untuk membimbing anaknya kepada kebaikan.Bila seorang anak sudah mencapai umur tujuh tahun, orangtua menyuruh anak-anaknya melaksanakan ibadah

11 Al-Iman Abu Zakariya Yahya Bin Syarif An-Nabawi,Terjemahan Riyadu Sholihin,Diterjemahkan oleh Ahmad Sunarto (Jakarta: Pustaka Amani, 1999), hlm. 318. 
salat.Orangtua harus membimbing, mengarahkan, dan membiasakan anak remaja mengerjakan ibadah salat.

\section{Bimbingan dalam Islam}

Bimbingan secara Islam merupakan proses pemberian bantuan dari seseorang pembimbing kepada individu. Dalam pelaksanaan pemberian bantuan, tidak boleh memaksakan kehendak atau kewajiban untuk mengikuti apa yang disarankannya, melainkan sekedar memberi arahan, bimbingan dan bantuan yang diberikan itu lebih terfokus kepada bantuan yang berkaitan dengan kewajiban/mental dan bukan yang berkaitan dengan material atau financial secara langsung. ${ }^{12}$ Menurut Hallen, bimbingan Islam adalah proses pemberian bantuan yang terarah, kontiniu dan sistematis kepada setiap individu agar ia dapat mengembangkan potensi atau fitrah beragama yang dimilikinya secara optimal dengan cara menginternalisasikan nilai-nilai yang sehingga ia dapat hidup selaras dan sesuai dengan tuntunan Al-Quran dan hadis. ${ }^{13}$ Dengan demikian bimbingan Islam merupakan proses bimbingan kepada individu untuk mencapai kebahagiaan hidup didunia dan akhirat dan berlandaskan Al-quran dan Hadis.

Selanjutnya tujuan dari bimbingan Islam adalah untuk memperoleh kebahagiaan dunia dan akhirat.Tujuan bimbingan Islam adalah untuk membantu individu mewujudkan dirinya sebagai manusia seutuhnya agar mencapai kebahagiaan dunia dan akhirat. ${ }^{14}$ Tujuan bimbingan Islam dapat dilihat dari dua aspek, yaitu:

1. Tujuan umum, yaitu membantu individu mewujudkan dirinya menjadi manusia seutuhnya agar dapat mencapai kebahagiaan dunia dan akhirat.

2. Tujuan khusus, yaitu:

a. Membantu individu agar tidak mempunyai masalah.

b. Membantu individu mengatasi masalah yang sedang dihadapi.

c. Membantu individu memelihara dan mengembangkan situasi dankondisi yang baik atau menjadi lebih baik, sehingga tidak menjadi sumber masalah bagi dirinya dan orang lain. ${ }^{15}$

Adapun fungsi bimbingan Islam diantaranya adalah :

1) Fungsi preventif atau pencegahan, yakni membantu individu menjaga atau mencegah timbulnya masalahbagi dirinya.

${ }^{12}$ Lahmuddin, Bimbingan Konseling Islam (Jakarta: Hijri Pustaka Utama, 2007),hlm. 5.

${ }^{13}$ Hallen, Bimbingan Dan Konseling Dalam Islam(Jakarta: Ciputar Pers, 2002), hlm. 17

${ }^{14}$ Lahmuddin, Bimbingan Konseling..., hlm. 24.

${ }^{15}$ Lahmuddin, Bimbingan Konseling..., hlm. 25. 
2) Fungsi kuratif atau pemahaman, yakni membantu individu memecahkan masalah yang sedang dihadapi atau dialaminya.

3) Fungsi preservative pengentasan, yakni membantu individu menjaga agar situasi dan kondisi yang semula tidak baik menjadi baik.

4) Fungsi developmental atau pengembangan, yakni membantu individu memelihara dan mengembangkan situasi dan kondisi yang telah baik atau menjadi lebih baik, sehingga tidak memungkinkannya menjadi sebab munculnya masalah baginya. ${ }^{16}$

Dengan demikian, untuk mencapai tujuan yang sejalan dengan fungsi bimbingan Islam, maka pembimbing dapat membantu terbimbing untuk mengenal, memahami dan menerima keadaan dirinya sehingga dapat mengarahkan dirinya kearah positif.

\section{Ibadah Salat}

Shalat secara etimologi berarti do'a kemudian secara istilah, suatu ibadah yang mengandung perkataan dan perbuatan tertentu yang diawali dengan takbir dan disudahi dengan salam. ${ }^{17}$ Shalat merupakan ibadah paling penting, yang bila dilakukan dengan benar dan penuh perhatian, amalan ini akan membuat ruh dan hati manusia menjadi lebih bersih dan bersinar. Dengannya juga akan mampu melepas dan mengubah akhlak-akhlak yang tak terpuji dan menggantikannya pada akhlak yang mulia. Pengertian lain dari salat ialah salah satu srana komunikasi antara hamba dengan tuhan-Nya sebagai bentuk ibadah yang didalamnya merupakan amalan yang tersusun dari beberapa perkataan dan perbuatan yang dimulai dengan takbiratul ihkram dan diakhiri dengan salam, serta sesuai dengan syarat dan rukun yang telah ditentukan syara'. ${ }^{18}$ Jadi salat merupakan ibadah kepada Tuhan, berupa perkataan dengan perbuatan yang diawali dengan takbir dan diakhiri dengan salam menurut syarat dan rukun yang ditentukan syara'.

Salat merupakan rukun kedua dari lima rukun Islam. Salat adalah suatu kewajiban dari Allah bagi setiap mukmin, Allah telah memerintahkannya dalam sejumlah firman-Nya yang tercantum dalam Al-Quran di antaranya terdapat dalam surat An-Nisa ayat 103:

${ }^{16}$ Thohari Musnamar, Dasar-Dasar Konseptual Bimbingan \& Konseling Islam (Yogyakarta: UII Press, 1992), hlm. 34

${ }^{17}$ Sayid Sabiq, Fiqh Sunnah, Jilid I (Beirul, Dar Al-Fikr, 1983), hlm. 78

${ }^{18}$ M. Zainal Arifin, Shalat Mikraj Kita Ke HadiratNya, (Jakarta: Raja Grafindo Persada, 1996), hlm.7. 


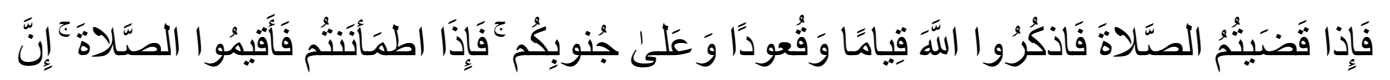

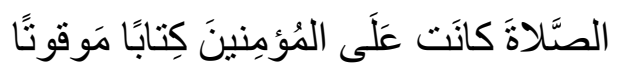

Artinya "Apabila kamu telah menyelesaikan salatmu, ingatlah Allah ketika kamu berdiri, pada waktu duduk dan berbaring. Kemudian apabila kamu telah merasa aman, Maka dirikanlah shalat, sesungguhnya shalat itu adalah kewajiban yang ditentukan waktunya atas orang-orang yang beriman". ${ }^{19}$

Bahwa mengingat Allah tidak hanya dalam salat, tetapi juga ketika berusaha maupun waktu istirahat.

Orang yang melaksanakan salat akan mendapat hikmah supaya terjaga dari perbuatan keji dan munkar. Hal ini sesuai dengan firman Allah SWT surat Al-Ankabut ayat 45:

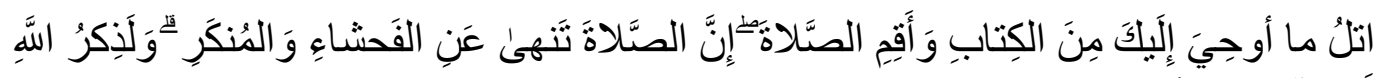

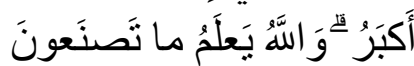

Artinya: "Bacalah apa yang telah diwahyukan kepadamu, Yaitu Al kitab (Al Quran) dan dirikanlah shalat. Sesungguhnya salat itu mencegah dari (perbuatan- perbuatan) keji dan munkar.Sesungguhnya mengingat Allah (salat) adalah lebih besar (keutamaannya dari ibadat-ibadat yang lain). dan Allah mengetahui apa yang kamu kerjakan" ${ }^{20}$

Dari ayat di atas dapat diketahui bahwa salat merupakan pencegah dari perbuatan keji dan munkar.

Salat juga menimbulkan dampak yang amat besar, bagi individu maupun kelompok, diantaranya:

1. Untuk mendekatkan diri kepada Allah

2. Memperkuat jiwa dan motivasi

3. Untuk menyatakan kemahatinggian Allah

4. Menimbulkan ketenangan jiwa

5. Menjauhkan diri dari kelalaian mengingat Allah

6. Melatih seseorang, untuk mencintai keteraturan dan kedisiplinan yang kuat dalam pekerjaan

7. Mengajarkan seseorang untuk memiliki sifat-sifat bijak, ketenangan dan kemuliaan

8. Membiasakan diri untuk berpikiran hal-hal yang positif

9. Melatih diri untuk membiasakan diri untuk bersikap positif, amanah dan jujur. ${ }^{21}$

${ }^{19}$ Departemen Agama R.I. Al-Quran dan Terjemahannya..., hlm. 95

${ }^{20}$ Departemen Agama R.I. Al-Quran dan Terjemahannya..., hlm. 635

${ }^{21}$ Jawadi Amuli, Rahasia Ibadah, ( Bogor: Penerbit Cahaya, 2004), hlm. 23 
156 | TAZKIR: Jurnal Penelitian Ilmu-ilmu Sosial dan Keislaman

Vol. 04 No. 1 Juni 2018

Dengan mengetahui manfaat dan faedah dalam salat seharusnya ummat Islam melaksanakannya tanpa paksaan.

\section{Remaja}

Remaja (adolescent) berasal dari adolescere yang berartitumbuh menjadi dewasa. Istilah adolescent mempunyai arti yang lebih luas yakni mencakup kematangan mental, emosional sosial dan fisik.22 Menurut Adams dan Gullota:

masa remaja meliputi usia antara 11 hingga 20 tahun. Adapun Hurlock membagi masa remaja awal (13 hingga 16 tahun) dan masa remaja akhir (16 hingga 18 tahun). Masa remaja awal dan akhir dibedakan oleh Hurlock karena pada masa remaja akhir individu telah mencapai transisi perkembangan yang lebih mendekati masa dewasa. ${ }^{23}$

Berdasarkan paparan diatas dapat dipahami bahwa remaja merupakan masa transisi dari masa kanak-kanak menuju masa dewasa yang terjadi proses perkembangan yang meliputi perubahan-perubahan dengan perkembangan fisik, agama dan juga terjadi perubahan dalam hubungan dengan orangtua.

\section{METODE PENELITIAN}

Penelitian ini dilakukan di Desa Pargarutan Dolok Kecamatan Angkola Timur pada bulan Mei 2017 sampai dengan Desember 2017. Jenis penelitian ini adalah penelitian lapangan (field recearch), dalam bentuk kualitatif dalam rangka memperoleh informasi dan mendiskripsikan peristiwa, kejadian yang terjadi di lapangan sesuai dengan fakta yang ditemukan di lapangan. Informan dalam penelitian ini adalah 10 orang dari orangtua, 10 orang dari 30 orang remaja berusia 15 - 18 tahun, tokoh agama, dan kepala desa. Teknik pengumpulan data melalui observasi dan wawancara. Data dianalisis melalui editing, reduksi, deskripsi, dan penarikan kesimpulan.

\section{HASIL PENELITIAN DAN PEMBAHASAN}

\section{Hasil Penelitian}

\section{Keadaaan pengamalan salat remaja di Desa Pargarutan Dolok}

Umumnya remaja di Desa Pargarutan Dolok mengetahui bahwa pelaksanaan salat itu wajib lima kali sehari semalam. Akan tetapi masih banyak

${ }^{22}$ Elisabert B Hurlock, Perkembanagn Suatu Pengantar Sepanjang Rentang Kehidupan (Jakarta: PT. Galora Aksara Pratama, 1980), hlm. 205.

${ }^{23}$ Yudrick Jahja, Psikologi Perkembangan (Jakarta : Kencana Prenada Media Group), hlm. 
juga remaja yang tidak mengerjakan salat di sebabkan karena mereka sibuk dengan HP androidnya. Peneliti melihat ketika waktu salat sudah masuk para remajanya masih banyak yang sibuk dengan aktivitasnya masing-masing dan dilihat dilokasi permainan seperti laki-lakinya masih sibuk dengan HP nya di kedai kopi. Peneliti juga melihat pada waktu pelaksanaan salat fardu sekian banyaknya remaja di Desa Pargarutan Dolok yang khususnya berusia 15-19 tahun, hanya sedikit ke mesjid yang melaksanakan salat. Kalau salat ashar, magrib, isya dan subuh hanya beberapa orang saja yang melaksanakan salat, setiap hasil observasi yang dilakukan peneliti dan bahkan tidak ada sama sekali. Sama halnya dengan observasi yang dilakukan peneliti dari rumah ke rumah bahwa yang mengerjakan salat sendirian peneliti juga menemukan masih banyak yang tidak melaksanakan salat dan sebagainya melaksanakan akan tetapi tidak sepenuhnya atau tidak rutin melaksanakan shalat fardu. Dan peneliti melihat para remaja masih sibuk dengan media sosial dan dalam diri remaja masih sangat rendah kesadaran beragamanya. ${ }^{24}$

Adapun hasil wawancara dengan ibu Mariati Nasution diperoleh informasi sebagai berikut:

Saya melihat penyebab anak saya terkadang tidak melaksanakan salat ia masih terikut-ikut teman-temannya, dan di rumah sibuk dengan HP nya.Ketika ditanya kenapa tidak melaksanakan salat jawabannya malas saya ibu, nanti saja ibu. Saya sudah membimbing anak saya bahkan selalu mengingatkannya untuk melaksankan salat, dan mengajaknya salat ketika saya hendak melaksanakan salat, akan tetapi terkadang anak saya sangat banyak alasan ketika disuruh melaksanakan salat. ${ }^{25}$

Kemudian hasil wawancara dengan ibu Halima diperoleh informasi bahwa dia melihat anak remaja sekarang susah untuk melaksnakan salat fardu, apalagi sekarang anak remaja yang mempunyai HP dan sibuk dalam menggunakan media sosial tidak mendengarkan apa yang dikatakan orangtuanya. ${ }^{26}$ Selanjutnya ibu Leli dan ibu Mas mereka mengatakan bahwa anak remaja sekarang sangat kurang dalam pelaksanaan salat fardu, bahkan suara azan pun tidak dipedulikan anak remaja karena sibuknya bermain, terutama bagi

${ }^{24}$ Observasi, di Desa Pargarutan Dolok. Tanggal 9 Januari 2018

${ }^{25}$ Mariati, orangtua remaja di Desa Pargarutan Dolok, Wawancara, Tanggal 12 Januari 2018

${ }^{26}$ Halima, Orangtua Remaja di Desa Pargarutan Dolok, Wawancara, Tanggal 12 Januari 2018 
158 | TAZKIR: Jurnal Penelitian Ilmu-ilmu Sosial dan Keislaman

Vol. 04 No. 1 Juni 2018

pengguna media sosial, yang sibuk dengan HP nya dan lupa kewajibannya sebagai umat muslim. ${ }^{27}$

Berdasarkan uraian di atas bahwa pengamalan salat remaja pengguna media sosial masih kurang dalam melaksnakan salat fardu bahkan suara azan pun tidak dipedulikan karena sibuk dalam menggunakan media sosial.

Adapun hasil wawancara dengan Elvina Sari sebagai anak remaja di Desa Pargarutan Dolok mengatakan bahwa:

Saya melaksanakan salat sesekali saja ketika saya ada waktu yaluang, biasanya saya mengerjakan salat magrib saja karena di situlah waktu saya yang lebih luang. Kalau diwaktu lainnya biasanya saya bermain di rumah teman, tapi terkadang saya di rumah main Facebook jadi saya malas untuk melaksanakan shalat. ${ }^{28}$

Selanjutnya wawancara dengan Maya sebagai anak remaja di Desa Pargarutan Dolok mengatakan bahwa: "Salat yang saya kerjakan kadang tiga kali sehari, kadang cuma satu waktu dan bahkan tidak pernah dalam sehari. Disebabkan karena malas, dan kadang main HP jadi lupa mau salat" ${ }^{29}$

Selanjutnya wawancara dengan bapak Damsir selaku tokoh agama di Desa Pargarutan Dolok diperoleh informasi bahwa:

Anak remaja sekarang tidak menghiraukan panggilan azan untuk melaksanakan disebabkan karena kebanyakan yang bermain HP dan menggunakan media sosial. Begitu juga orangtua remaja yang kurang kesadaran remaja untuk melaksanakan ibadah salat sehungga remaja mengikuti kepribadian orangtua. ${ }^{30}$

Dari keterangan di atas dapat disimpulkan bahwa kewajiban salat remaja masih diabaikan, dan masih lebih mementingkan bermain HP daripada melaksanakan salat.Dan peneliti melihat minimnya kesadaran beragama pada diri remaja sehingga kewajiban-kewajiban sering terabaikan karena terlena dengan dunia semata.

\section{Upaya orangtua dalam melaksanakan bimbingan terhadap ibadah salat remaja pengguna media sosial}

Upaya orangtua adalah usaha yang dilakukan orangtua dalam membimbing dan mengarahkan anak kepada pengamalan agama khususnya Januari 2018

27 Leli Sebagai Petani, Mas Sebagai Petani, Orangtua Remaja,Wawancara, Tanggal 19

\footnotetext{
${ }^{28}$ Elvina Sari, Remaja di Desa Pargarutan Dolok, Wawancara, Tanggal 14 Januari 2018

${ }^{29}$ Maya, Remaja di Desa Pargarutan Dolok, Wawancara, Tanggal 7 Januari 2018

${ }^{30}$ Damsir, Tokoh Agama, Wawancara, Tanggal 26 Januari 2018
} 
dibidang ibadah salat fardu. Dalam membimbing pelaksanaan ibadah salat remaja di Desa Pargarutan Dolok, orangtua melakukan berbagai upaya antara lain, sebagai berikut:

\section{Memberikan Nasehat kepada remaja}

Nasehat merupakan hal yang paling utama dalam membimbing anak. Nasehat juga merupakan memberikan jalan atau petunjuk serta memberikan teguran yang baik pada remaja.Orang yang paling diwajibkan menasehati anak adalah orangtunya. Hasil wawancara ibu Mariati dan ibu Delima mereka mengatakan bahwa: "Saya sering memberikan nasehat kepada anakanak saya, apalagi sekarang anak-anak yang punya HP android lupa semuanya, apalagi tentang salat. Termasuk adekmu yang di rumah juga, jadi kita sebagai orangtua harus bisa memantau anak-anaknya apalagi tentang salat karena shalat itukan sebagai kewajiban bagi setiap muslim. Jadi saya memberikan nasehat pada anak saya jangan pernah tinggalkan shalat sesibuk apapun." 31

Hal yang sama dengan hasil wawancara dengan Ibu Sarifa, tindakan yang dilakukannya dalam membimbing pelaksanaan salat remaja yaitu dengan memberikan nasehat dan arahan kepada anak saya kalau sibuk dengan media sosial dan tidak melaksanakan salat fardu, kalau kita seorang muslim sudah kewajiban kita untuk melaksanakan shalat fardu agar terhindar dari perbuatan maksiat. Saya tidak melarang anak saya memiliki HP android tapi jangan lupa melaksanakan salat fardu.Apalagi sekarang sudah remaja sudah kita yang menanggung dosa kita bukan lagi orangtua makanya sekarang harus dibiasakan untuk melaksanakan salat fardu. ${ }^{32}$

Hal yang berbeda dengan hasil wawancara dengan ibu Halimah dan ibu Santi mereka mengatakan bahwa: "Saya jarang memberikan nasehat kepada anak saya karena menurut saya mereka lebih tahu tentang agama daripada saya karena mereka sudah saya sekolahkan, apalagi sekarang sudah menginjak remaja jadi saya cuma menyuruhnya saja untuk salat.Saya juga tidak melarang mereka untuk bermain HP." ${ }^{33}$

${ }^{31}$ Mariati, Delima, Orangtua Remaja di Desa Pargarutan Dolok, Wawancara, Tanggal 19 Januari 2018

32Sarifa, Orangtua di Desa Pargarutan Dolok, Wawancara, Tanggal 07 Januari 2018.

${ }^{33}$ Halimah, Santi, Orangtua Remaja di Desa Pargarutan Dolok, Wawancara, Tanggal 12 dan 14 Januari 2018 
Kemudian hasil wawancara dengan ibu Nilam dan Ibu Anni yang mengatakan bahwa: "Saya pernah memberikan nasehat kepada anak saya tapi tidak sering karena waktunya tidak ada.Saya berikan nasehat sekedar mengingatkannya saja agar melaksanakan shalat.Saya juga mengatakan pada anak saya jangan terlalu sibuk bermain $\mathrm{HP}^{\prime \prime} .{ }^{34}$ Adapun hasil wawancara dengan Wisda sebagai anak remaja di Pargarutan Dolok diperoleh informasi sebagai berikut: “Orangtua saya pernah memberikan nasehat kepada saya agar melaksanakan shalat apalagi salat subuh, ibu saya membangunkan saya agar salat, tapi saya malas bangun karena masih pagi dan cuacanya pun dingin jadi saya malas untuk bangun dan ujung-ujungnya salatnyapun gak jadi." 35

Adapun hasil wawancara dengan Sahrul sebagai anak remaja Pargarutan Dolok di peroleh informasi: "Kalau saya ya kak orangtua saya pernah menasehati saya kalau tidak melaksanakan salat tapi yang sering orangtua saya menasehati saya kalau sudah azan berkumandang tapi belum masuk kerumah.Orangtua saya gak suka kak, karena orangtua saya bilang biarpun gak shalat setidaknya kalau sudah azan jangan lagi diluar. Apalagi bermain HP bersama teman-teman saya kak, ibu saya pasti marah kalau sudah ada di rumah." 36

Dari hasil wawancara dan observasi yang dilakukan, ddiambil kesimpulan bahwa kebanyakan orangtua memberikan nasehat bagi anakanaknya untuk melaksanakan ibadah salat. Namun kebanyakan orangtua belum maksimal dalam menasehati pelaksanaan ibadah salat remaja, karena sebagian orangtua hanya menasehati tetapi tidak memantaunya karena kesibukan orangtua yang mencari nafkah untuk keluarganya.

2. Menyuruh anak untuk melaksanakan salat

Orangtua harus senantiasa menyuruh anak untuk melaksanakan salat, karena salat merupakan salah satu kegiatan ibadah yang wajib dilaksanakan oleh setiap muslim. Semua itu didasarkan atas kebijakan orangtua dalam membimbing anaknya agar mau melaksanakan salat yaitu dengan menyuruh

34 Nilam dan Anni Sebagai Petani, Orangtua Remaja di Desa Pargarutan Dolok, Wawancara, Tanggal 8dan 12 januari 2018

${ }^{35}$ Wisda, Remaja di Desa Pargarutan Dolok, Wawancara, Tanggal 14 Januari 2018

${ }^{36}$ Sahrul, Remaja di Desa Pargarutan Dolok, Wawancara, Tanggal 14 Januari 2018 
anak untuk melaksanakn salat. Sebagai hasil wawancara dengan ibu Nilam Siregar diperoleh informasi sebagai berikut:

Upaya yang saya lakukan dalam pelaksanaan salat anak saya adalah dengan menyuruhnya untuk salat.Tapi saya tidak mempunyai waktu luang untuk memantau apakah dia melaksanakannya atau tidak.Terkadang saya sampai rumah sudah adzan magrib dan anak saya masih berada di luar rumah.Sedangkan saya masih banyak kesibukan harus saya lakukan seperti mandi kemudian salat.Jadi saya hanya menyuruhnya saja untuk melaksanakan salat. ${ }^{37}$

Hal yang sama dengan hasil wawancara kepada ibu Anni dan ibu Halima mereka mengatakan bahwa :

“Upaya yang saya lakukan untuk pelaksanaan salat anak saya adalah dengan menyuruhnya untuk shalat.Namun terkadang hanya salat magrib saja karena kadang saya pulang dari sawah anak saya sudah pergi bermain dan anak saya baru pulang kerumah sesudah menjelang magrib.Sehingga cuma itu yang saya memiliki waktu untuk memantau shalat anak saya." 38

Adapun hasil wawancara dengan ibu Santi diperoleh informasi bahwa "Saya jarang menyuruh anak remaja saya untuk melaksanakan salat, karena menurut saya anak saya sudah tahu mana yang baik. Karena dia sudah sekolah jadi saya serahkan sama anak saya apakah dia melaksanakn salat atau tidak"39

Kemudian hal yang berbeda dengan wawancara ibu Mariati Nasution dan ibu Delima mengatakan bahwa :

"Upaya yang saya lakukan untuk pelaksanaan salat anak saya adalah dengan menyuruhnya untuk salat lima waktu, saya selalu mengingatkan anak saya untuk salat sebelum ia pergi bermain dengan teman-temannya, dan terkadang dia ada dirumah dan sibuk bermain HP. Saya ambil HP itu dari tangannya dan saya tidak kembalikan sebelum dia melaksanakan salat walaupun shalatnya kadang sudah di ujung waktu." 40

Hasil wawancara dengan Maya dan Devi sebagai anak remaja di

Desa Pargarutan Dolok ia juga mengatakan bahwa:

Saya aktip dalam menggunakan media sosial.Saya akui saya juga malas untuk melaksanakan salat. Tapi orangtua saya selalu menyuruh saya untuk salat lima waktu bahkan sering orangtua

\footnotetext{
${ }^{37}$ Nilam Sebagai Petani, Orangtua Remaja di Desa Pargarutan Dolok, Wawancara, Tanggal 8 januari 2018

38 Anni, Halima Sebagai Petani, Orangtua Remaja di Desa Pargarutan Dolok, Wawancara, Tanggal 12 januari 2018

${ }^{39}$ Santi sebagai petani, Orangtua Remaja di Desa Pargarutan Dolok, Wawancara, Tanggal 14 Januari 2018

40 Mariati Seabagai Wiraswasta, Delima Sebagai Petani, Orangtua Remaja di Desa Pargarutan Dolok, Wawancara, Tanggal 12 Januari 2018
} 
saya menanyakan apakah saya sudah salat atau belum sehingga terkadang saya berdusta kepada orangtua saya dengan mengatakan bahwa saya sudah salat padahal sebenarnya saya belum melaksanakan salat karena saya takut dimarahi orangtua saya. Salat yang paling rutin saya laksanakan setiap hari adalah salat magrib dan subuh. ${ }^{41}$

Walaupun banyak orangtua yang menyuruh anak remajanya untuk salat, namun berbeda halnya dengan Andika yang menyatakan bahwa orangtuanya tidak pernah menyuruh untuk salat kecuali kecuali salat jum'at. Orantuanya juga tidak melarang Andika menggunakan HP kapan saja. Saya jarang melaksanakan salat fardhu dan saya juga jarang melihat orangtua saya melaksanakan salat" 42

Dari hasil setelah melakukan observasi dengan ibu Nilam memang benar bahwa ibu ini sangat sibuk bekerja setiap hari di kebun kopinya. Sehingga ibu Nilam jarang mempunyai waktu luang dalam penyuruh anaknya untuk melaksanakan salat. Dan menurut pengamatan peneliti sendiri bahwa ibu Nilam ini sering pulang bekerja setelah adzan magrib sudah berkumandang dan anak-anaknya pun masih bermainmain diluar rumah. ${ }^{43}$ Menurut pengamatan peneliti juga tidak pernah melihatnya salat di masjid, dan berdasarkan wawancara dengan Erwin sebagai anak dari ibu Nilam iamengatakan bahwa memang tidak pernah salat di masjid maupun dirumah. ${ }^{44}$ Sesuai juga dengan pengamatan peneliti bahwa anak dari ibu ini pun sering masih diwarung kopi dan bermain HP walaupun adzan magrib sudah berkumandang.

Kemudian hasil observasi setelah melakukan wawancara bahwa peneliti dapat melihat memang benar ibu Mariati Nasution dan ibu Delima menyuruh anaknya untuk melaksanakan salat lima kali sehari semalam. Ini dapat dilihat ketika bahwa anak ibu Mariati ini juga melaksanakan shalat magrib dan salat isya di masjid bersama orangtuanya. ${ }^{45}$

Dari beberapa pernyataan diatas dapat diketahui bahwa upaya orangtua dalam membimbing pelaksanaan ibadah salat remaja pengguna

\footnotetext{
${ }^{41}$ Maya, Devi, Remaja di Desa Pargarutana Dolok, Wawancara, Tanggal 7 Januari 2018

${ }^{42}$ Andika, Remaja di Desa Pargarutan Dolok, Wawancara, Tanggal 13 Januari 2018

${ }^{43}$ Observasi, di Desa Pargarutan Dolok, Tanggal 9 januari 2018

${ }^{44}$ Erwin, Remaja di Desa Pargarutan Dolok, Wawancara, Tanggal 8 januari 2018

${ }^{45}$ Observasi, di Desa Pargarutan Dolok, Tanggal 12 Juni 2017
} 
media sosial masih kurang. Karena sebagian orangtua hanya menyuruhnya saja untuk melaksanakan salat tapi tidak memantaunya apakah remaja pengguna media sosial tersebut melaksanakan salat fardu atau tidak.Dikarenakan juga orangtua di Desa Pargarutan Dolok yang sibuk dalam mencari nafkah untuk keluarganya.

3. Hambatan orangtua dalam membimbing pelaksanaan ibadah salat remaja

Ada beberapa hambatan yang dihadapi orangtua dalam membimbing pelaksanaan ibadah salat remaja di Desa Pargarutan Dolok Kecamatan Angkola Timur yaitu sebagi berikut:

a. Faktor kurangnya kesadaran beragama

Berdasarkan observasi penulis bahwa, masih ada remaja yang kurang kesadaran beragama untuk melaksanakan ibadah salat. Sebagai tanda-tandanya anak-anak remaja tidak mempedulikan panggilan suara azan untuk salat dan sibuk melaksanakan aktivitas. Dari hasil wawancara Bersama beberapa orangtua remaja, didapat kesimpulan bahwa kesadaran anak remaja di desa ini masih kurang dalam melaksanakan aktifitas beragama. ${ }^{46}$ Bapak Ruslan sebagai tokoh masyarakat sekaligus orangtua remaja di Desa Pargarutan Dolok, juga diperoleh informasi bahwa masih banyak remaja yang tidak menghiraukan nasehat orangtua dan panggilan azan untuk melaksanakan ibadah shalat yang disebabkan kurang kesadaran remaja untuk melaksanakan ibadah salat, begitu juga orangtua yang kurang kesadaran untuk mengamalkan ibadah shalat sehingga remaja mengikuti kepribadian orangtua. ${ }^{47}$

Sehingga peneliti mengambil kesimpulan bahwa kesadaran beragama anak remaja masih kurang, sehingga masih sangat perlu untuk ditingkatkan.

b. Faktor ekonomi dan pekerjaan

Berdasarkan observasi penulis, bahwa kesibukan orangtua bekerja akibat minimnya ekonomi sehingga magrib sampai kerumah dan tidak sempat memantau pelaksanaan ibadah shalat remaja,

46 Mariati, Dkk, Orangtua Remaja di Desa Pargarutan Dolok, Wawancara, Tanggal 19 Januari 2018

47 Ruslan, Orangtua Remaja di Desa Pargarutan Dolok, Wawancara, Tanggal 12 Januari 2018 
karena kelelahan bekerja dan butuh waktu istirahat. ${ }^{48}$ Hal ini sesuai dengan dengan hasil wawancara dengan bapak Hamid selaku Kepala Dusun Pargarutan Dolok yang menyatakan bahwa, kesibukan bekerja akibat minimnya ekonomi merupakan hambatan yang dihadapi orangtua dalam membimbing ibadah shalat remaja. Kesibukan bekerja menyebabkan orangtua kurang memperhatikan dan memantau salat remaja. Sehingga remaja lalai terhadap kewajibannya kepada sang pencipta bila dinasehati menjadi melawan, tidak menghiraukannya bahkan membantah dan berbohong. ${ }^{49}$

Dalam hal yang sama wawancara dengan ibu Mas, Nilam, Anni dan ibu Halima mengatakan bahwa "Kesibukan mencari nafkah karena minimnya ekonomi menyebabkan sedikit waktu untuk membimbing pelaksanaan shalat remaja. Adapun remaja sekarang selalu sibuk dengan media sosial" ${ }^{50}$

Kemudian ibu Mariati, Delima, Sarifa dan ibu Santi mereka engatakan bahwa:

Kesibukan bekerja dan mencari nafkah, kami sebagai orangtua jadi tidak ada waktu untuk memantau dan membimbing pelaksanaan ibadah salat remaja kami. Semua orangtua pasti menginginkan anaknya selalu melaksanakan shalat. Tetapi anak remaja sekarang lebih pentingan $\mathrm{Hp}$ nya daripada nasehat orangtuanya" 51

Keperluan untuk mencari kehidupan menjadikan orangtua tidak memiliki waktu yang cukup buat anak-anaknya untuk mengawasi dan mengontrol pelaksanaan beragama anak-anaknya.

c. Faktor pengetahuan

Berdasarkan observasi penulis bahwa, pengetahuan agama orangtua dan remaja yang kurang akan berpengaruh terhadap pelaksanaan ibadah salat fardu remaja. Sehingga remaja cenderung malas dan tidak menghiraukan ibadah salat fardu yang merupakan

${ }^{48}$ Observasi, di Desa Pargarutan Dolok, Tanggal 7 Januari 2018

${ }^{49}$ Hamid, Kadus di Desa Pargarutan Dolok, Wawancara, Tanggal 12 Januari 2018

50 Mas, Dkk, Orangtua Remaja di Desa Pargarutan Dolok, Wawancara, Tanggal 8,12,19 Januari 2018

51 Mariati, Dkk, Orangtua Remaja di Desa Pargarutan Dolok, Wawancara, Tanggal 19 Januari 2018 
kewajiban yang harus dilaksanakan oleh setiap umat Islam. ${ }^{52}$ Selanjutnya wawancara dengan bapak Damsir selaku tokoh agama di Desa Pargarutan Dolok menyatakan bahwa, kurangnya pengetahuan orangtua dalam membimbing ibadah salat membuat remaja kurang memahami makna salat dengan benar bahkan menjadi malas untuk melaksanakan ibadah salat. ${ }^{53}$ Factor pengetahuan keagamaan yang kurang membuat orangtua merasa bahwa memberikan pengatahuan kepada anak remaja mereka bukanlah suatu kewajiban.

d. Faktor berbagai macam media

Ada beberapa media yang menjadi hambatan bagi orangtua dalam membimbing pelaksanaaan ibadah salat remaja yaitu: adanya televisi dan handphone. Adanya kedua media tersebut menjadikan para remaja asyik dengan kesibukannya menonton televisi dan bermain handphone.

\section{PEMBAHASAN}

Sejalan dengan hasil pengamatan dan hasil wawancara penelitian bahwa sebagian orangtua di Desa Pargarutan Dolok Kecamatan Angkola Timur dalam membimbing pelaksanaan salat remaja belum maksimal walaupun sebagian orangtua telah melakukan bimbingan untuk pelaksanaan ibadah salat remaja seperti menyuruh remaja untuk melaksanakan salat dan menasehati remaja agar melaksanakan salat.Oleh karena itu hasil pengamatan peneliti sejalan dengan wawancara kepada orangtua dan remaja yang ada di Desa Pargarutan Dolok.

Dari setiap wawancara kepada orangtua bahwa kebanyakan orangtua menyatakan bahwa mereka sudah melakukan bimbingan ibadah salat remaja, khususnya pelaksanaan salat fardu.Sejalan dengan yang disampaikan orangorang bahwa orangtua remaja di Desa Pargarutan Dolok sudah melakukan upaya untuk membimbing pelaksanaan ibadah salat remaja dengan menyuruh, menasehati dan mengajak remaja untuk melaksanakan salat. Penulis menyimpulkan bahawa upaya orangtua dalam membimbing pelaksanaan salat remaja pengguna media sosial di Desa Pargarutan Dolok Kecamatan Angkola Timur Kabupaten Tapanuli Selatan belum maksimal dengan apa yang

\footnotetext{
52 Observasi, di Desa Pargarutan Dolok, Tanggal 5 Januari 2018

${ }^{53}$ Damsir, Tokoh Agama, Wawancara, Tanggal 26 Januari 2018
} 
166 | TAZKIR: Jurnal Penelitian Ilmu-ilmu Sosial dan Keislaman

Vol. 04 No. 1 Juni 2018

diharapkan, karena banyak orangtua yangtidak peduli terhadap pelaksanaan salat fardu remaja.

Hasil penelitian yang penliti peroleh, dapat dibandingkan dengan hasil penelitian orang lain, salah satunya Reni Harsita ${ }^{54}$ yang memfokuskan mengenai tanggung jawab orangtua terhadap pengamalan shalat remaja. Hasil akhir penelitian ini, pengamalan shalat remaja masih kurang baik karena orangtua belum maksimal dalam membimbing pengamalan agama remaja dikarenakan sibuk dalam mencari nafkah. Penelitian ini juga mempunyai persamaannya dengan penelitian terdahulu yaitu sama-sama membahas kearah bidang ibadah, sama-sama menggunakan jenis metode penelitian kualitatif, sama-sama menggunakan wawancara dan observasi dalam metode pengumpulan metode pengumpulan data yang diteliti oleh penulis. Hal ini senada dengan hasil penelitian yang peneliti lakukan, bahwasanya remaja masih sulit untuk melakukan salat tanpa dipaksa. Penelitian Ahmad Fikri pada tahun $2011^{55}$ telah menemukan bahwa pada kenyataannya perhatian dari orangtua merupakan faktor pertama dan utama yang paling berpengaruh untuk meningkatkan kegiatan keagamaan anak.

Penelitian yang dilakukan penulis mempunyai perbedaan dengan penelitian terdahulu.Adapun perbedaannya yaitu dari segi judul, lokasi, waktu, tempat, fokus masalah dan bidang agama yang diteliti. Dari pembahasan pertama belum ada yang khusus membahas tentang upaya orangtua dalam membimbing pelaksanaan ibadah shalat remaja pengguna media sosial.

\section{PENUTUP}

Setelah penulis melakukan penelitian di lokasi penelitian, maka selanjutnya dapat diperoleh kesimpulan bahwa ada upaya orangtua dalam membimbing ibadah salat remaja pengguna media sosial di desa Pargarutan Dolok Kecamatan Angkola Timur Kabupaten Tapanuli Selatan. Hal yang dilakukan adalah dengan cara orangtua mengajak remaja agar salat terutama pada salat magrib, menyuruh dan menasehati remaja agar melaksanakan salat fardu. Dalam hal pelaksanaan pengamalan salat remaja pengguna media sosial di desa Pargarutan Dolok Kecamatan Angkola Timur masih diabaikan, dan masih lebih mementingkan bermain HP daripada melaksanakan salat, dan

\footnotetext{
${ }^{54}$ Reni Harsita, Skripsi Mahasiswa IAIN Padangsidimpuan, 2016

${ }^{55}$ Ahmad Fikri, Skripsi Mahasiswa IAIN Padangsidimpuan, 2011
} 
mminimnya kesadaran beragama pada diri remaja sehingga kewajibankewajiban sering terabaikan karena terlena dengan dunia semata. Adapun hambatan yang dihadapi orangtua dalam membimbing pelaksanaan ibadah shalat remaja di desa Pargarutan Dolok Kecamatan Angkola Timur Kabupaten Tapanuli Selatan, yaitu faktor kurangnya kesadaran beragama remaja, faktor ekonomi dan pekerjaan, faktor pengetahuan, dan faktor pengaruh dari berbagai media televise dan handphone.

Dari hasil temuan penelitian ini disarankan bagi orangtua agar membina jiwa beragama remaja sejak mulai dari dalam kandungan dan sesudah lahir agar tumbuh sebagai remaja yang beriman, menyeimbangkan kebutuhan dunia dan kebutuhan akhirat sehingga perhatian terhadap remaja tidak terabaikan. Orangtua juga jangan mengabaikan pendidikan terutama pendidikan yang berbasis keagamaan dan memantau setiap kegiatan yang dilakukan remaja, jika yang dilakukan itu tidak baik agar dibimbing dan jika itu baik, agar mendapat dukungan. Orangtua menyarankan agar membuat suatu kelompok belajar AlQuran di masjid sesudah salat magrib dengan menghadirkan guru mengaji. Orangtua yang membimbing pelaksanaan salat fardu remaja yang baik memerlukan pembinaan dan pemahaman serta pembiasaan.

Bagi remaja agar remaja memiliki kesadaran untuk melaksanakan salat fardu dan jangant terlalu sibuk dalam menggunakan media sosial sehingga lupa akan kewajiban sebagai seorang muslim. Jangan mengabaikan pendidikan terutama pendidikan yang berbasis keagamaan dan jangan mudah terpengaruh oleh lingkungan yang merugikan diri sendiri. Bagi tokoh agama disarankan agar memberi nasehat kepada remaja jika perilaku tidak sesuai dengan ajaran agama Islam. Berpartisipasi untuk mengajak remaja untuk melaksanakan salat fardu berjama'ah di masjid. 
168 | TAZKIR: Jurnal Penelitian Ilmu-ilmu Sosial dan Keislaman

Vol. 04 No. 1 Juni 2018

\section{DAFTAR PUSTAKA}

Afrizal, Metode Penelitian Kualitatif , Jakarta: PT Raja Grafindo Persada, 2014

Al-Iman Abu Zakariya Yahya Bin Syarif An-Nabawi, Terjemahan Riyadu Sholihin diterjemahkan oleh Ahmad Sunarto, Jakarta: Pustaka Amani, 1999

Bambang Syamsul Arifin, Psikologi Agama, Bandung: Pustaka Setia, 2008

Departemen Agama R.I. Al-Quran Dan Terjemahannya, Jakarta : Al Faith, 2005.

Departemen Pendidikan dan Kebudayaan, Kamus Besar Bahasa Indonesia, Jakarta: Balai Pustaka, 2002.

Depdikbud. Kamus Besar Bahasa Indonesia, Jakarta: Balai Pustaka. 2001.

Elisabert B Hurlock, Perkembanagn Suatu Pengantar Sepanjang Rentang Kehidupan, Jakarta: PT. Galora Aksara Pratama, 1980

Elisabert B Hurlock, Perkembanagn Suatu Pengantar Sepanjang Rentang Kehidupan Jakarta: PT. Galora Aksara Pratama, 1980

Fenti Hikmawati, Bimbingan Konseling, Jakarta: Rajawali Pers, 2011.

Hasbih Ash Siddieqy \& Teungku Muhammad, Kuliah Ibadah: Ibadah Ditinjau Dari Segi hukum Dan Hikmah, Semarang: pustakarizki Putra, 2000

Jalaluddin, Psikologi Agama, Jakarta: PT Raja Grafindo Persada, 2000

Jawadi Amuli, Rahasia Ibadah, Bogor: Penerbit Cahaya, 2004

Khalili Musthafa, Berjumpa Allah Dalam Shalat, Jakarta: Pustaka Zahra, 2004

Koentjoroningrat, Metode Penelitian Masyarakat, Jakarta: Gramedia, 1981

Lahmuddin, Bimbingan Konseling Islam, Jakarta: Hijri Pustaka Utama, 2007

Lexy J. Moleong, Metodologi Penelitian Kualitatif ( Edisi Revisi), Bandung : PT. Remaja Rosdakarya, 2002

M. Zainal Arifin, Shalat Mikraj Kita Ke Hadiratnya, Jakarta: Raja Grafindo Persada, 1996

Nurul Zuriah, Metodologi Penelitian Sosial Dan Pendidikan, Jakarta: PT Bumi Aksara 2006

Rosady Ruslan, Metodologi Penelitian Publik Relation \& Komunikasi, Jakarta: Raja Grafindo Persada, 2004

Rulli Nasrulli, Media Sosial Perspektif Komunikasi, Budaya Dan Sosioteknologi, Bandung: Simbiosa Rekatama Media, 2015 
Saleh Al-Fauzan, Penerjemah Abdul Hayyie, Fiqh Sehari-Hari, Jakarta: Gema Insane Pers 2005.

Sayid Sabiq, Fiqh Sunnah, Jilid I, Beirul, Dar Al-Fikr, 1983

Senot Haryanto, Psikologi Shalat, yogyakarta: Mitra Pustaka, 2001.

Shiefti Dyah Alyusi, Media Sosial: Intraksi, Identitas, Dan Modal Sosial, Jakarta: Kencana, 2016

Sugiyono, Metode Penelitian Manajemen, Bandung:Alfabeta,2013

Suharsimi Arikunto, Prosedur Penelitian Suatu Pendekatan Peraktek, Jakarta: Rineka Cipta, 2006

Syahrul Ramadhan, Kamus Ilmiah Popular, Surabaya: Khazanah Media Ilmiah, 2010.

Syamsu Yusuf dan A. Juntika Nurihsan, Landasan Bimbingan \& Konseling, Bandung: PT Remaja Rosdakarya, 2009

Syamsu Yusuf, Psikologi Perkembangan Anak \& Remaja, Bandung: PT. Rosdakarya, 2011.

Thohari Musnamar, Dasar-Dasar Konseptual Bimbingan $\mathcal{E}$ Konseling Islam, Yogyakarta: UII Press, 1992

Tohirin. “Bimbingan Dan Konseling Di Sekolah Dan Madrasah." In Jakarta: PT RajaGrafindo Persada, 173, 2014.

http://journal2.um.ac.id/index.php/sembk/article/view/1475/786.

Winarno Suharman, Dasar Metode Teknik Penelitian, Bandung: Tarsito, 1985

Yudrick Jahja, Psikologi Perkembangan, Jakarta : Kencana Prenada Media Group

Http://Tenzatekno. Blogspot.Com, Dampak Positif Dan Negative Media Sosial, Pada Tanggal 23/07/2017 Pukul 09:25 WIB 
170 | TAZKIR: Jurnal Penelitian Ilmu-ilmu Sosial dan Keislaman

Vol. 04 No. 1 Juni 2018

\title{
VALIDITAS DAN RELIABILITAS INSTRUMEN KECEMASAN BELAJAR MATEMATIKA PADA SISWA MADRASAH ALIYAH SWASTA
}

\author{
Nurmawati \& Irma Suryani \\ IAIN Langsa \\ nurma16@ymail.com
}

